\title{
Phenology of Didymella rabiei Development on Chickpea Debris Under Field Conditions in Spain
}

\author{
J. A. Navas-Cortés, A. Trapero-Casas, and R. M. Jiménez-Díaz
}

First and second authors: Departamento de Agronomía, Escuela Técnica Superior de Ingenieros Agrónomos y de Montes (ETSIAM), Universidad de Córdoba (UCO), Apdo. 3048, E-14080 Córdoba, Spain; third author: Departamento de Agronomía, ETSIAM, UCO and Instituto de Agricultura Sostenible, Consejo Superior de Investigaciones Científicas, Apdo. 4084, E-14080 Córdoba, Spain.

Current address of J. A. Navas-Cortés: Instituto de Agricultura Sostenible, Consejo Superior de Investigaciones Científicas, Apdo. 4084, E14080 Córdoba, Spain.

Accepted for publication 11 June 1998.

\begin{abstract}
Navas-Cortés, J. A., Trapero-Casas, A., and Jiménez-Díaz, R. M. 1998. Phenology of Didymella rabiei development on chickpea debris under field conditions in Spain. Phytopathology 88:983-991.

The development of Didymella rabiei on debris of naturally infected chickpea was investigated in four chickpea-growing areas with different climatic conditions in Spain during 1987 to 1992. D. rabiei extensively colonized chickpea debris and formed pseudothecia and pycnidia. Differentiation of pseudothecial initials occurred regularly across experimental locations by November, 1 month after placement of debris on the soil. Ascospore maturation occurred mainly from late January to late March, depending on location and year. Maximum ascospore discharge from sampled debris pieces placed under suitable environmental conditions occurred 2 to 4 weeks after ascospore maturation, after which ascospore release decreased sharply. Pseudothecia were exhausted, due to asco-

first season. Ascospore maturation and liberation in cooler locations were more uniform and occurred later compared to maturation in warmer locations. Also, production of asci and ascospores per pseudothecium was much higher in cooler than in warmer locations. A similar relationship was found for density of pseudothecia and pycnidia and conidia production per pycnidium. The percentage of mature pseudothecia increased according to the logistic model, with the cumulative number of Celsius degree days calculated by computing the mean of the maximum and minimum daily air temperatures on rainy days from the date of debris placement on the soil. There were significant differences among model parameter estimates between cooler and warmer locations, but minor differences were found among parameters for locations with similar environmental conditions. There was an inverse linear relationship between the average temperature during the period of pseudothecia maturation and the number of asci produced per pseudothecium.
\end{abstract} spore discharge, by the beginning of summer. New asci did not develop in empty pseudothecia and no pseudothecia formed in tissues after the
Additional keywords: Ascochyta blight, Cicer arietinum.
Ascochyta blight, caused by Ascochyta rabiei (Pass.) Labrousse, is one of the most important diseases of chickpea (Cicer arietinum L.) worldwide (19). The annual economic losses caused by the disease in the Palouse Region of eastern Washington and northern Idaho alone may exceed $\$ 1$ million (11). In Spain, the disease occurs sporadically in spring sowings but can be destructive in winter sowings as well (22). The fungus attacks all aboveground plant parts at any stage of crop development, causing necrotic lesions that often girdle stems and kill plant parts above the lesions (19). Pycnidia develop extensively in necrotic tissues and produce conidia for secondary infections when suitable environmental conditions occur. The number of secondary infection cycles occurring during a growing season depends largely on the rate of disease development, which is influenced by environment and cultivar susceptibility (19).

A. rabiei forms the sexual or teleomorphic stage (Didymella rabiei (Kovachevski) von Arx (=Mycosphaerella rabiei Kovachevski)) on chickpea debris that overwinter on the soil surface, developing saprophytically and forming abundant pycnidia and pseudothecia $(13,17,23)$. D. rabiei is heterothallic, with a bipolar diallelic incompatibility system (26). Under field conditions in the Palouse Region and southern Spain, pseudothecial development begins during the fall and winter seasons, and ascospores of the fungus are discharged into the air beginning at the end of the winter season and continuing until the end of the spring season $(16,23)$. Asco-

Corresponding author: R. M. Jiménez-Díaz

E-mail address: ag1jidir@lucano.uco.es

Publication no. P-1998-0714-02R

(C) 1998 The American Phytopathological Society spores may be carried great distances by wind (11) and are the major primary inoculum for epidemics of Ascochyta blight (24). These factors, together with the possibility of the teleomorph contributing to increased genetic diversity in the pathogen population (26), emphasize the importance of elucidating the environmental conditions required for teleomorph formation.

Some studies have been carried out under laboratory conditions to determine the environmental factors that influence the development of $D$. rabiei pseudothecia and production of ascospores $(16,18,23)$. However, there is little information on the effects of these factors under field conditions. Based on laboratory experiments, either constant $100 \%$ relative humidity $(\mathrm{RH})$ or alternating wet $(100 \% \mathrm{RH})$ and dry (34\% RH) periods are required for pseudothecial production and maturation $(16,18,23)$. If moisture is not limiting for pseudothecial production, temperatures of 5 to $10^{\circ} \mathrm{C}$ are required for pseudothecial maturation (23). Pseudothecia mature at $10^{\circ} \mathrm{C}$ and constant $100 \% \mathrm{RH}$ and at 5 and $10^{\circ} \mathrm{C}$ and alternating 100 and $34 \% \mathrm{RH}(16$, 18). At temperatures higher than $10^{\circ} \mathrm{C}$ or $<100 \% \mathrm{RH}$, pseudothecia do not form or mature, and cell contents degenerate $(16,18)$.

The objective of our research was to determine the phenology of D. rabiei pseudothecial development on chickpea debris under field conditions in the major chickpea-growing regions of Spain. Information from this research contributes to a better understanding of the epidemiology of Ascochyta blight.

\section{MATERIALS AND METHODS}

Chickpea debris and experimental plots. From July 1987 to 1991, stem debris of highly susceptible chickpea cv. Blanco Lechoso $(21,22)$ naturally infected by $D$. rabiei was collected at har- 
vest time from fields of chickpea in the Córdoba Province, Spain, severely affected by Ascochyta blight during the spring of each year. Stem debris from uninfected plants of the same cultivar was collected from disease-free fields and used as a control. The debris was air-dried and stored in sacks in a dry place at room temperature $\left(\approx 18\right.$ to $\left.24^{\circ} \mathrm{C}\right)$ until used. Dried, infested stem debris was cut into 10 - to $12-\mathrm{cm}$-long pieces that had at least two necrotic lesions with pycnidia typical of $A$. rabiei. Twelve stem pieces were placed in nylon net bags $(14 \times 20 \mathrm{~cm})$ with $1.6-\mathrm{mm}$ mesh. During October of each year from 1987 to 1991, 30 bags containing stem debris were placed on the soil surface in a $4 \times 3-\mathrm{m}$ plot at each location during each season. The bags were held in place by a large net attached to the soil to prevent dispersal of the bags and stem pieces by wind. Plots were located in fields of Experimental Research Stations at Chipiona, Cádiz Province (1988 to 1991); Córdoba (1987 to 1991); Atarfe, Granada Province (1987 to 1991); and Zamadueñas, Valladolid Province (1988 to 1991), Spain. These locations are representative of the main chickpeagrowing areas in Spain and were selected on the basis of differences in prevailing climatic conditions. The provinces of Cádiz, Córdoba, and Granada are located in southern Spain, and Valladolid is located in northern Spain. For each experimental plot and season, the contents of one bag with infested stem debris was sampled from October to July at monthly intervals during the
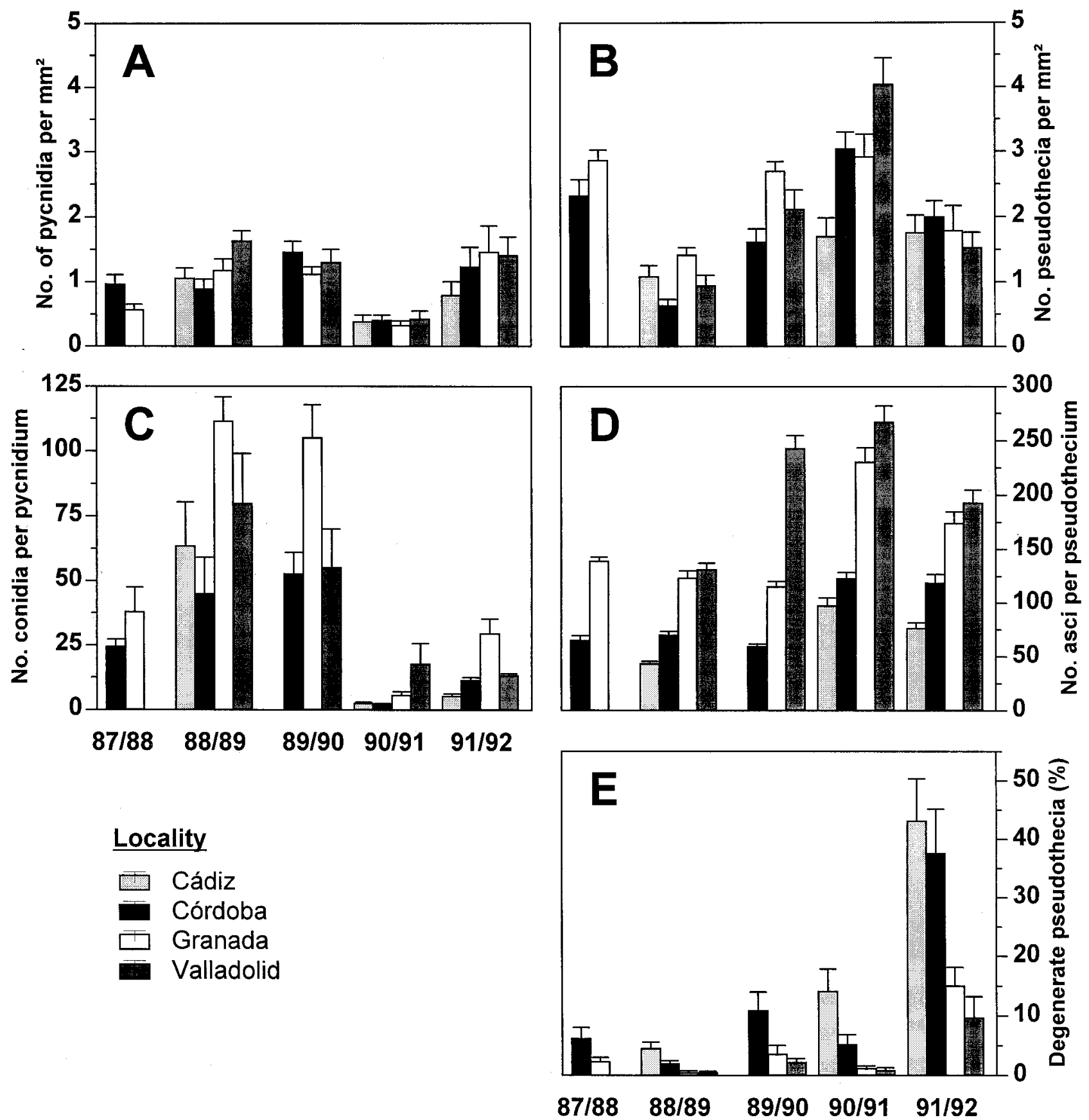

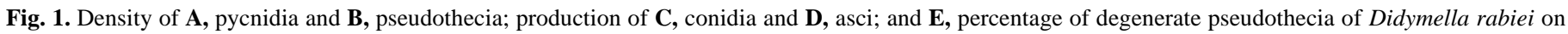

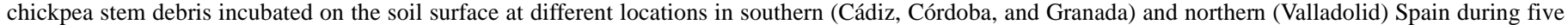

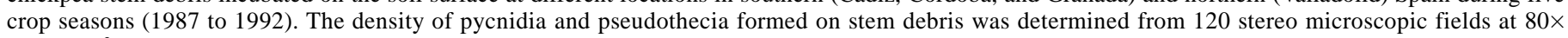

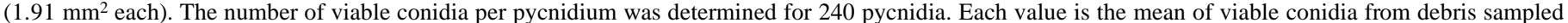

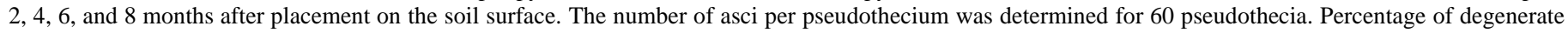

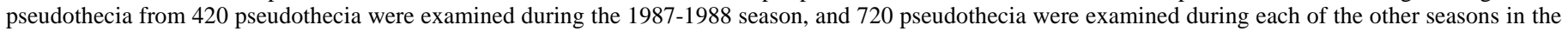
study. Vertical bars indicate the standard error of the mean. 
1987-1988 season and at 2-week intervals during the 1988-1989 to 1991-1992 seasons. The contents of one bag with pieces of diseasefree chickpea stems was sampled at 2-month intervals during the same time period.

Assessment of fungal development on chickpea debris. Sampled chickpea stem pieces were washed under running tap water for 2 min, dried on filter paper, and assessed for pseudothecial development and ascospore production of $D$. rabiei. To assess pseudothecial development, 50 pseudothecia were dissected from the tissue, squashed in lactophenol-acid fuchsin, and microscopically examined at 200 and $400 \times$ to determine their developmental stage. Pseudothecia were rated according to internal stage of development: stage 1, stromatic pseudothecial initial; stage 2, pseudoparaphyses filling the lumen of the pseudothecium; stage 3, appearance of asci among pseudoparaphyses; stage 4, asci formed but content not differentiated; stage 5, asci with ascospores forming or completely formed and mature, very few pseudoparaphyses remaining; stage 6, empty or half-empty asci and released ascospores; and stage 7, empty pseudothecium, all ascospores discharged (23).

To estimate ascospore production within pseudothecia, strips of tissue colonized by pseudothecia were placed on $2 \%$ water agar (WA: $20 \mathrm{~g}$ of agar, 1 liter of deionized water) until they covered a 4- $\mathrm{cm}^{2}$ area. The WA block was attached to the inner surface of the lid of a sterile petri plate, ascospores were allowed to discharge downward onto WA or into sterilized water in darkness at $20 \pm 1{ }^{\circ} \mathrm{C}$ for $24 \mathrm{~h}$, and discharged ascospores were counted.

The number of fungal fruiting bodies (pycnidia and pseudothecia) per square centimeter of tissue (fruiting body density) and spore production in pycnidia were determined in pieces of stem debris sampled 2, 4, 6, and 8 months after placement on the soil surface. To determine fruiting body density, stem pieces were observed with a dissecting microscope at $80 \times$. Fruiting bodies in five microscope fields $\left(1.91 \mathrm{~mm}^{2}\right.$ each) from each of six stem pieces were removed, squashed in lactophenol-acid fuchsin, and characterized as pycnidia or pseudothecia of $D$. rabiei under a microscope at $400 \times$. The total number of pycnidia and pseudothecia was calculated for each sampled piece of debris. To determine conidial production, 10 pycnidia were removed from each of six stem pieces, placed in a drop of sterile deionized water, macerated with a pestle to obtain a homogeneous conidial suspension, and a serial dilution was spread evenly on acidified WA $(0.25 \mathrm{ml}$ of $85 \%$ lactic acid per liter of WA) in petri dishes. The dishes were incubated at $20 \pm 1{ }^{\circ} \mathrm{C}$ in darkness for 10 days, and the number of $D$. rabiei colonies growing on the agar plates was counted. The number of conidia per pycnidium was estimated from the mean number of colonies of $D$. rabiei formed per pycnidium in macerates, assuming that each colony developed from a single conidium. The production of asci and ascospores per pseudothecium was determined for 60 selected pseudothecia in which the asci appeared to be mature, with the ascospores well differentiated (stage 5). Pseudothecia were squashed on microscope slides, stained with lactophenol-acid fuchsin, and examined under a microscope at $400 \times$.

Data analyses. Data were analyzed by standard analysis of variance, using factorial treatment designs in which time of sampling and location were treatment factors A and B, respectively. In the analysis of the extent of saprophytic colonization, the 2-week and 1-month assessments were the sample units. Analyses of the density of fruiting bodies and the number of conidia per pycnidium were performed, using the four assessments made at 2-month intervals as sample units. Trend analysis, based on orthogonal polynomials for treatments with equal intervals for time of sampling (4), were carried out for each plot and season. Analyses of the number of asci per pseudothecium were carried out with the 60 pseudothecia sampled as replications. Significant interactions $(P \leq 0.05)$ were analyzed by partitioning the interaction

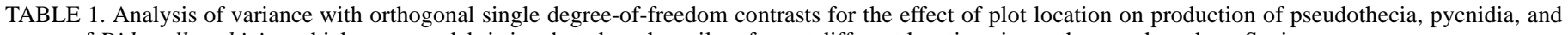
spores of Didymella rabiei on chickpea stem debris incubated on the soil surface at different locations in southern and northern Spain

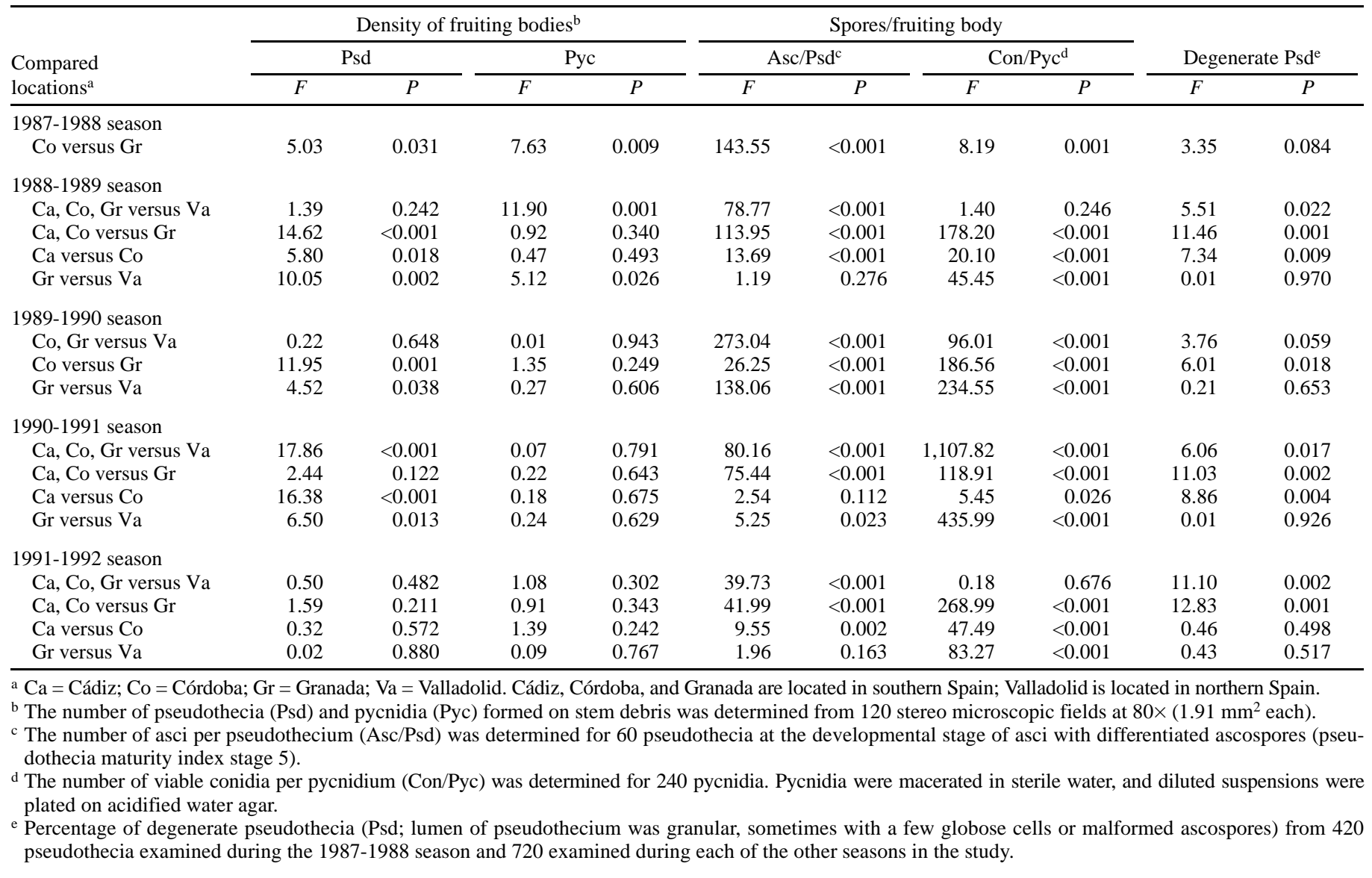


sum of squares. Orthogonal, single degree-of-freedom contrasts were computed to analyze the effect of plot location (4). Contrast statements for location were constructed by geographic region, as well by average temperatures for locations within region. Data were analyzed using Statistix 1.0 win (Analytical Software, Tallahassee, FL).

Nonlinear regression analyses were carried out to describe pseudothecial maturation progress data for each location and season. The least-squares program for nonlinear models (NLIN procedure with Marquardt's compromise method) of Statistical Analysis System 6.11 (SAS Institute Inc., Cary, NC) was used to obtain estimates of parameters in the model. Coefficient of determination $\left(R^{2}\right)$, standard error (SE), significance of estimated parameters, and pattern of residuals plotted against expected values were used to assess the goodness-of-fit of the data to the model (1). The following form of the logistic model was fitted to the data: $M P=$ $k /\{1+\exp [-\beta(C D D-\delta)]\}$, in which $M P$ is the percentage of mature pseudothecia; $k$ is the asymptote; $\beta$ is the rate parameter; $\delta$ is the location parameter; and $C D D$ is the cumulative number of Celsius degree days, using a base temperature of $0^{\circ} \mathrm{C}$. Degree-day accumulation was calculated by computing the mean of the maximum and minimum daily air temperatures on rainy days $(1 \mathrm{~mm}$ of rain), beginning with the day chickpea stem debris were placed on the soil surface each season. Meteorological data were obtained from meteorological stations located 0 to $4 \mathrm{~km}$ from the experimental plots. To statistically compare $M P$ progress curves, the estimated values and confidence intervals $(P=0.05)$ for nonlinear parameters $\beta$ and $\delta$ were used (1).

\section{RESULTS}

Production of fruiting bodies of $D$. rabiei on chickpea stem debris. D. rabiei grew saprophytically on pieces of infested chickpea stem debris overwintering on the soil surface and formed pycnidia and pseudothecia within 4 to 8 weeks after placement of debris on the soil surface. The density of fruiting bodies that developed was influenced primarily by season; smaller differences were found among locations (Fig. 1A and B).

Overall, the density of pycnidia developing on debris was similar across the seasons, except for the 1990-1991 season, which had the lowest density of pycnidia (Fig. 1A). Similarly, the density of pycnidia formed on stem debris was not significantly different $(P>$ 0.05) among locations within a season, except for the 1987-1988 and 1988-1989 seasons. A significantly $(P \leq 0.05)$ higher density of pycnidia formed on debris located at Córdoba (southern Spain) during the 1987-1988 season and at Valladolid (northern Spain) during the 1988-1989 season (Fig. 1A; Table 1). Sampling date did not influence the density of pycnidia formed on stem debris across seasons, except for 1987-1988, in which a significant $(P \leq 0.05)$ quadratic trend for pycnidia density over time was found (Table 2 ).

The density of pseudothecia formed on stem debris was higher during the 1987-1988, 1989-1990, and 1990-1991 seasons compared to the other seasons studied (1988-1989 and 1991-1992) (Fig. 1B). Although there were large differences among locations, in general the lowest density of pseudothecia formed on stem debris located in plots at Cádiz and Córdoba (southern Spain) compared to those formed on stem debris located at Granada (southern Spain) and Valladolid (northern Spain) (Fig. 1B; Table 1). No significant trend $(P>0.05)$ was observed for the density of pseudothecia over the four assessment dates, except for a significant $(P \leq 0.05)$ negative linear trend at Cádiz during the 1990-1991 season and a significant $(P \leq 0.05)$ quadratic trend at Valladolid during the 1988-1989 season and at Granada during the 1990-1991 season (Table 2).

In general, the density of pseudothecia that formed on stem debris was higher than that of pycnidia. The average percentages of pseudothecial density with respect to the density of all fruiting bodies formed on stem debris were 67, 63, 71, and 60\% at Cádiz,

TABLE 2. Trend analysis ${ }^{\mathrm{a}}$ based on orthogonal polynomials for the effect of sampling date on production of pseudothecia, pycnidia, and conidia by Didymella rabiei on chickpea stem debris incubated on the soil surface at different locations in southern (Cádiz, Córdoba, and Granada) and northern (Valladolid) Spain

\begin{tabular}{|c|c|c|c|c|c|c|c|c|c|}
\hline \multirow[b]{3}{*}{ Location } & \multicolumn{6}{|c|}{ Density of fruiting bodies ${ }^{b}$} & & & \\
\hline & \multicolumn{3}{|c|}{ Pseudothecia } & \multicolumn{3}{|c|}{ Pycnidia } & \multicolumn{3}{|c|}{ No. of conidia/pycnidium ${ }^{c}$} \\
\hline & $F$ & $P$ & Trend & $F$ & $P$ & Trend & $F$ & $P$ & Trend \\
\hline Córdoba & 2.23 & 0.116 & $\mathrm{~ns}$ & 9.75 & $<0.001$ & $\mathrm{~L}, \mathrm{Q}$ & 15.52 & 0.001 & Q \\
\hline Granada & 2.42 & 0.096 & ns & 3.71 & 0.028 & $\mathrm{~L}, \mathrm{Q}$ & 258.90 & $<0.001$ & All \\
\hline \multicolumn{10}{|c|}{ 1988-1989 season } \\
\hline Granada & 1.14 & 0.357 & $\mathrm{~ns}$ & 2.57 & 0.083 & $\mathrm{~ns}$ & 4.90 & 0.032 & $\mathrm{~L}$ \\
\hline Valladolid & 5.75 & 0.005 & Q & 2.02 & 0.143 & ns & 59.85 & $<0.001$ & $\mathrm{~L}, \mathrm{Q}$ \\
\hline \multicolumn{10}{|c|}{ 1989-1990 season } \\
\hline Córdoba & 0.81 & 0.501 & ns & 1.03 & 0.401 & $\mathrm{~ns}$ & 39.45 & $<0.001$ & All \\
\hline Granada & 0.86 & 0.479 & ns & 1.93 & 0.158 & ns & 64.29 & $<0.001$ & All \\
\hline Valladolid & 0.19 & 0.901 & ns & 1.01 & 0.409 & ns & 172.03 & $<0.001$ & All \\
\hline Valladolid & 0.64 & 0.600 & ns & 2.63 & 0.079 & $\mathrm{~ns}$ & 440.34 & $<0.001$ & All \\
\hline \multicolumn{10}{|c|}{ 1991-1992 season } \\
\hline Cádiz & 1.39 & 0.274 & $\mathrm{~ns}$ & 1.71 & 0.198 & ns & 7.66 & 0.010 & $\mathrm{~L}$ \\
\hline Córdoba & 0.28 & 0.841 & ns & 1.16 & 0.348 & $\mathrm{~ns}$ & 2.78 & 0.110 & ns \\
\hline Granada & 1.31 & 0.298 & $\mathrm{~ns}$ & 2.60 & 0.081 & $\mathrm{~ns}$ & 89.84 & $<0.001$ & All \\
\hline Valladolid & 2.40 & 0.098 & ns & 1.93 & 0.157 & ns & 1.54 & 0.277 & ns \\
\hline
\end{tabular}

a $\mathrm{ns}=$ no significant $(P>0.05)$ trend; $\mathrm{L}=\operatorname{significant}(P \leq 0.05)$ linear trend; $\mathrm{Q}=\operatorname{significant}(P \leq 0.05)$ quadratic trend; $\mathrm{C}=\operatorname{significant}(P \leq 0.05)$ cubic trend; All $=\mathrm{L}$, $\mathrm{Q}$, and $\mathrm{C}$ all significant $(P \leq 0.05)$. Stem debris was sampled 2, 4, 6, and 8 months after placement on the soil surface at each location and during each season.

$\mathrm{b}$ The number of pseudothecia and pycnidia formed on stem debris was determined from 120 stereo microscopic fields at $80 \times\left(1.91 \mathrm{~mm}^{2}\right.$ each).

${ }^{c}$ The number of viable conidia per pycnidium was determined for 240 pycnidia. Pycnidia were macerated in sterile water, and diluted suspensions were plated on acidified water agar. 
Córdoba, Granada, and Valladolid, respectively, and ranged from 45 to $88 \%$ during the five seasons studied. Only during the 19881989 season was the density of pycnidia formed slightly higher than that of pseudothecia (Fig. 1A and B).

Spore production in pycnidia and pseudothecia. Both the number of viable conidia produced per pycnidium and the number of asci that developed per pseudothecium were significantly $(P \leq 0.05)$ influenced by season and location in the study (Fig. 1C and D; Table 1).

The number of viable conidia produced per pycnidium was highest during the 1988-1989 and 1989-1990 seasons, decreased slightly during the 1987-1988 season, and was lowest during the 19901991 and 1991-1992 seasons (Fig. 1C). In each season, the number of viable conidia produced per pycnidium was higher on stem debris located at Granada and Valladolid than the number for debris located at Cádiz and Córdoba (Fig. 1C; Table 1). Conidia production per pycnidium varied with sampling time, with the number of viable conidia per pycnidium showing a significant $(P \leq 0.05)$ nonlinear trend over time (Table 2). Nevertheless, no specific trend was associated consistently with locations or seasons in the study (Table 2). Frequently, maximum and minimum numbers of viable conidia produced per pycnidium were observed in pycnidia sampled 4 and 8 months after stem debris was placed on the soil surface, respectively (data not shown).
The mean number of asci formed per pseudothecium varied among seasons. However, for each season a significantly $(P \leq 0.05)$ lower number of asci per pseudothecium developed on stem debris located at Cádiz and Córdoba compared to the number observed at Granada and Valladolid (Fig. 1C; Table 1). During the seasons studied, the mean number of asci formed per pseudothecium on stem debris located at Cádiz, Córdoba, and Granada represented 35,42 , and $75 \%$, respectively, of the mean number of asci formed per pseudothecium on debris located at Valladolid.

Phenology of pseudothecial development. Important differences were observed in the phenology of pseudothecial development of D. rabiei on infested chickpea stem debris among experimental locations and seasons (Fig. 2). Differentiation of pseudothecial initials (stage 1) occurred within 2 to 4 weeks of placement of infested stem debris on the soil surface. Subsequently, pseudoparaphyses developed to fill the lumen of pseudothecia (stage 2). Stage 2 occurred during December 1987 and 1989 and January 1988, 1990, and 1991. Furthermore, large differences in subsequent pseudothecial development among experimental locations and seasons were observed (Fig. 2).

Pseudothecial development of D. rabiei at Cádiz (southern Spain), the warmest of the experimental locations, was very irregular and differed greatly from development observed in the other locations (Fig. 2). Frequently, pseudothecia degenerated, and production of
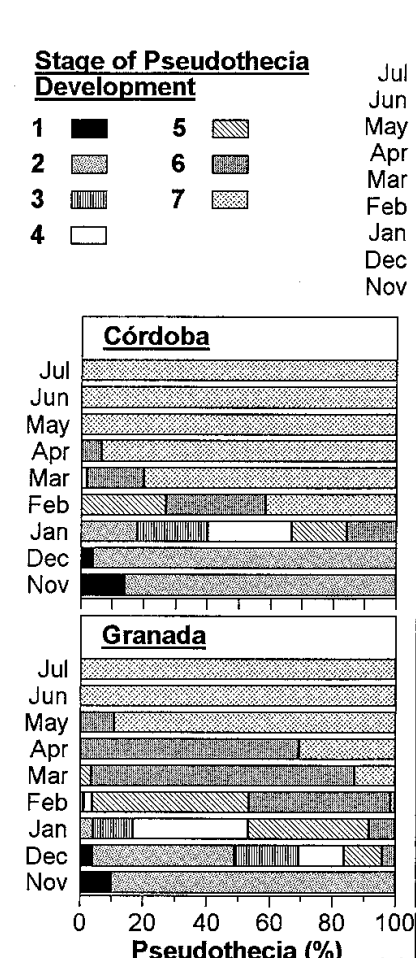

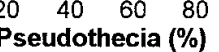

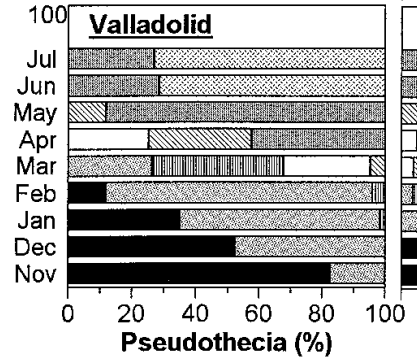

$\underline{1987 / 88}$
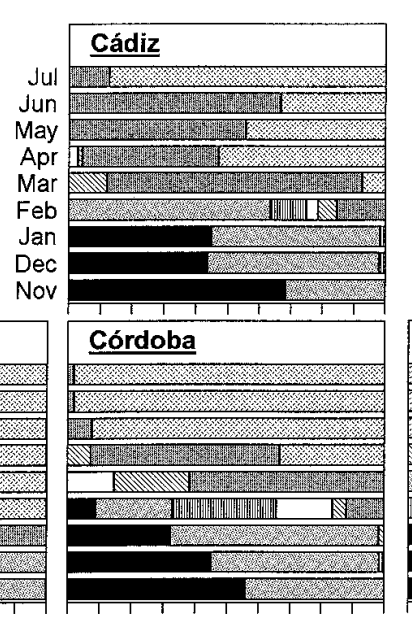
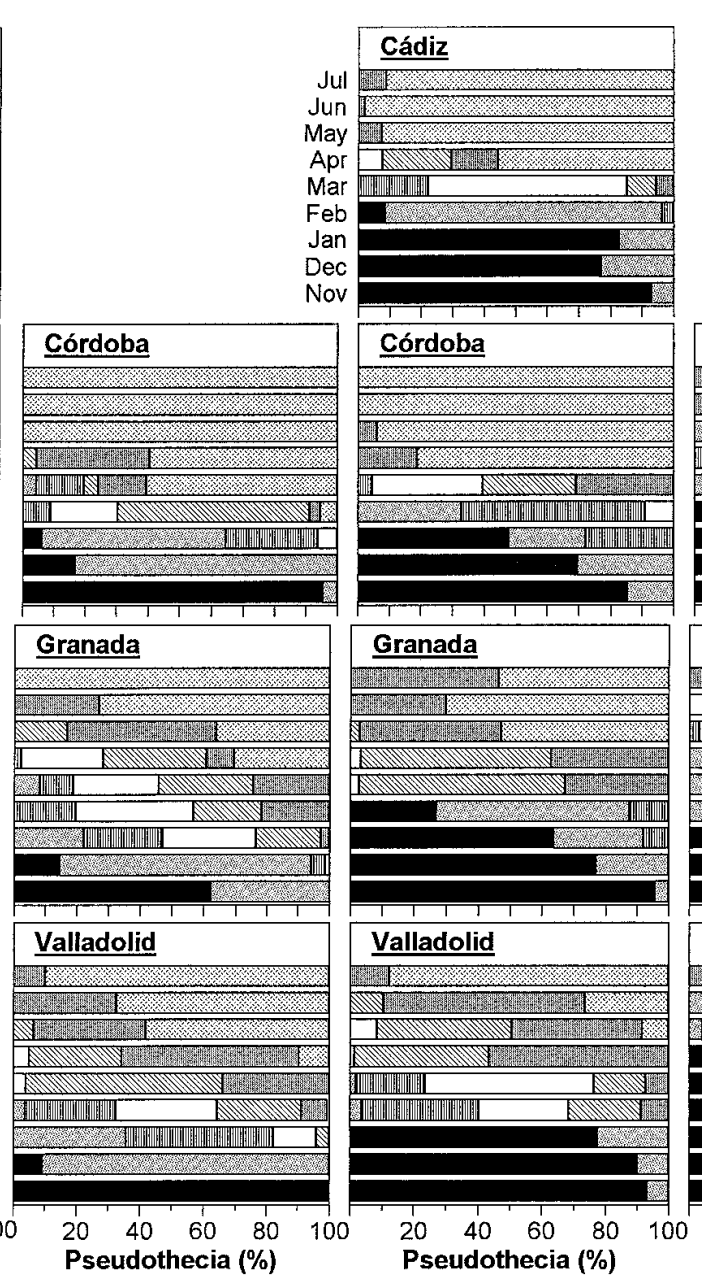

$\underline{1989 / 90}$

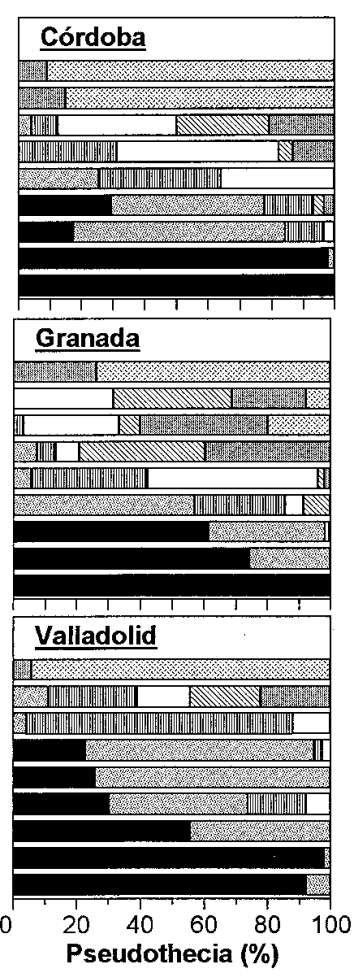

$\underline{1991 / 92}$

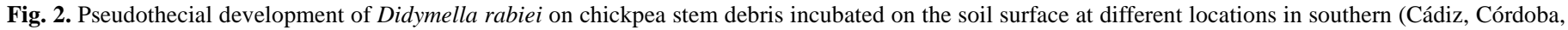

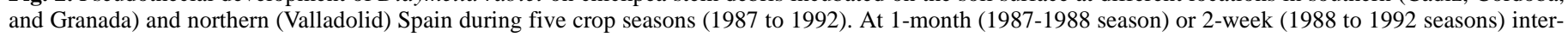

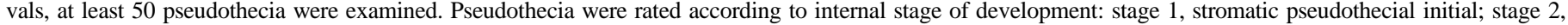

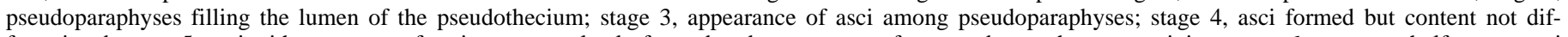

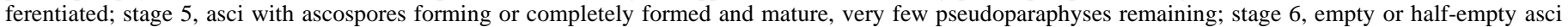
and released ascospores; and stage 7, empty pseudothecium, all ascospores discharged. 
mature ascospores was very limited (Fig. 1E; Table 1). In degenerate pseudothecia, after development of pseudoparaphyses, the internal content of the pseudothecial lumina became granular, and pseudoparaphyses were mixed with globose structures and malformed ascospores. Either asci- or ascospore-like structures developed within degenerate pseudothecia. Mature ascospores developed at this location from the beginning of February to mid-March during the 19881989 and 1990-1991 seasons (Fig. 2). During the 1989-1990 season,
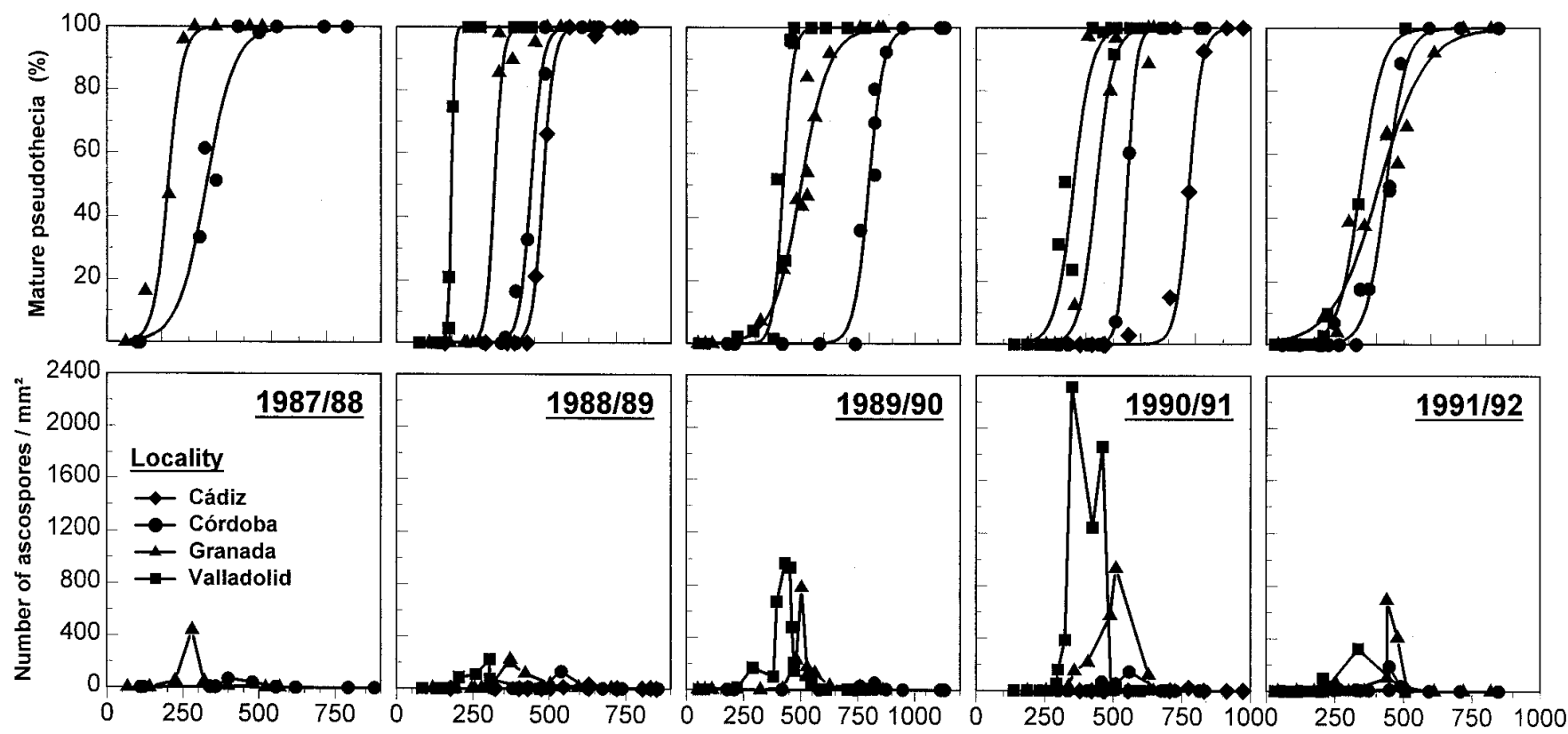

Degree-days (base $0^{\circ} \mathrm{C}$ )

Fig. 3. Pseudothecial development of Didymella rabiei on chickpea stem debris incubated on the soil surface at different locations in southern (Cádiz, Córdoba, and Granada) and northern (Valladolid) Spain. Upper panel: increase of mature pseudothecia over cumulative number of Celsius degree days (base $0^{\circ} \mathrm{C}$ ), computed using the mean of the maximum and minimum daily air temperatures on rainy days ( $\geq 1 \mathrm{~mm}$ of rain). The solid line represent the predicted mature pseudothecia progress curve calculated by the logistic model. Lower panel: ascospore discharge from stem debris placed under conditions suitable for ascospore release. Years indicate crop season.

TABLE 3. Nonlinear regression analysis for fitting the increase in the percentage of mature pseudothecia of Didymella rabiei over Celsius degree-day accumulation on rainy days to the logistic model for chickpea stem debris with D. rabiei incubated on the soil surface at different locations in southern (Cádiz, Córdoba, and Granada) and northern (Valladolid) Spain

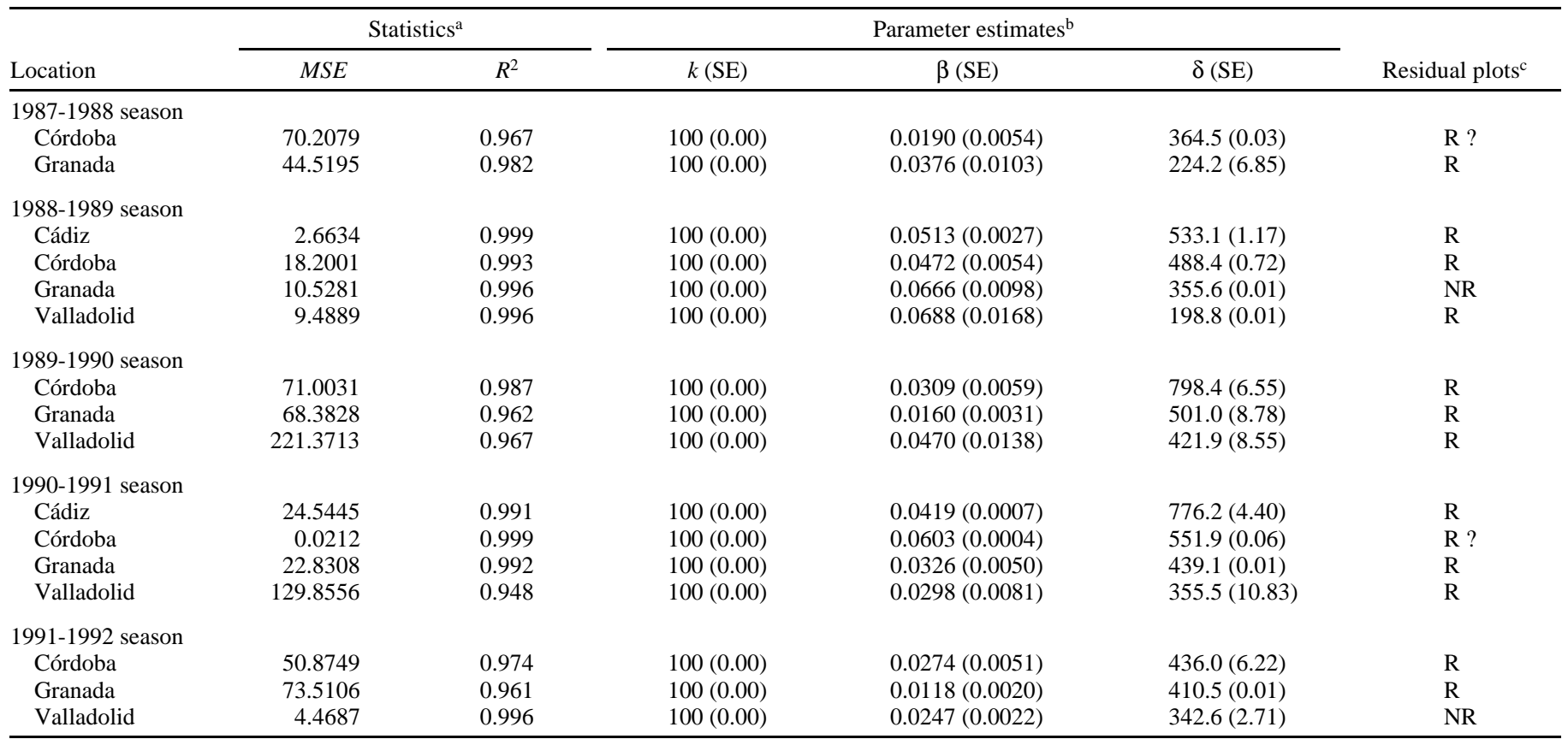

${ }^{a} M S E=$ final mean square error; $R^{2}=$ coefficient of determination.

${ }^{\mathrm{b}}$ Logistic model fitted to the data: $M P=k /\{1+\exp [-\beta(C D D-\delta)]\}$, in which $M P$ is the percentage of mature pseudothecia; $k$ is the asymptote; $\beta$ is the rate parameter; $\delta$ is the location parameter; and $C D D$ is the number of Celsius degree-days accumulated on rainy days, using a base temperature of $0{ }^{\circ} \mathrm{C}$. SE $=$ standard error.

${ }^{c}$ Standardized residuals plotted against $M P$ values observed or predicted from nonlinear regression analysis. Letters indicate patterns of residuals with a random scatter (R), nonrandom scatter (NR), or scarcely discernible scatter (R?) after visual inspection of residual plots. 
heavy rains occurred in the Cádiz experiment area, causing partial destruction of the experimental plot, as a result the data for this period were discarded.

The phenology of pseudothecial development of $D$. rabiei on infested stem debris was more regular at the other experimental locations in this study. During the first four seasons, 1987 to 1991, differentiation of asci and ascospores (stage 5) occurred from lateJanuary and the beginning of February at Córdoba and Granada (southern Spain), respectively, until the beginning of March at both locations (Fig. 2). At Valladolid (northern Spain), mature asci and ascospores formed from late to mid-March. Conversely, during the 1991-1992 season, this same pseudothecial developmental stage occurred at the beginning and during mid-May at Córdoba and Granada, respectively, and during early June at Valladolid (Fig. 2). Degeneration of pseudothecia also was observed on stem debris overwintering at Córdoba. At Córdoba, the percentage of degenerate pseudothecia ranged from 1.9 to $11.5 \%$ during the five seasons studied (Fig. 1E). Abnormal pseudothecial development was rarely observed at Granada and Valladolid, where the level of degenerate pseudothecia ranged from 0.4 to $3.5 \%$ (Fig. 1E; Table 1).

In all locations and seasons studied, maximum ascospore discharge from stem debris occurred 2 to 4 weeks after pseudothecia reached ascospore maturation (stage 5). Low discharges of ascospores were obtained during the 2- to 3-week periods previous and subsequent to the date of maximum ascospore discharge, respectively (Fig. 3). Ascospore discharge decreased drastically after reaching maximum levels and was scarce or nil by June or, exceptionally, by July 1992. After exhaustion of pseudothecia, no more ascospores were produced, and pseudothecial walls degenerated. For each season in the study, the highest discharges of ascospores were obtained from pseudothecia that developed on stem debris overwintered at Granada and Valladolid, whereas the lowest ascospore discharges were obtained from debris overwintered at Córdoba and Cádiz (Fig. 3).

Pycnidia and pseudothecia of D. rabiei did not develop on healthy chickpea stem debris incubated next to the stem debris of naturally infected chickpea stems. However, saprophytic colonization by several other fungi was observed. Genera more frequently observed included Alternaria, Chaetomium, Leptosphaeria, Mycosphaerella, Pleospora, and Stachybotris.

Table 3 shows the parameter estimates and related statistics for logistic fits to the increase over cumulative degree days in the percentage of mature pseudothecia of $D$. rabiei that developed on stem debris incubated at different locations and seasons. The logistic model adequately described all $M P$ progress data (Table 3). $R^{2}$ ranged from 0.948 to 0.999 , and there was no discernible pattern in the distribution of residuals for most of the $M P$ progress curves (Table 3).

There was no evidence for any effect on the asymptote parameter due either to season or location in the study (Table 3). The asymptote value reached $100 \%$ of mature pseudothecia for all $M P$ progress curves (Table 3 ). However, both season and location strongly influenced the rate $(\beta)$ and location ( $\delta$ )parameters (Fig. 4; Table 3 ). Except for minor differences, estimates of $\beta$ and $\delta$ showed an overall trend of significant $(P \leq 0.05)$ increase and decrease, respectively, for equations fitted to data obtained from stem debris located at Cádiz, Córdoba, Granada, and Valladolid, in that order (Fig. 3; Table 3).

When the logistic nonlinear parameter estimates ( $\beta$ and $\delta$ ) for the $M P$ progress curves were pooled, linear regression analyses showed a significant relationship between the average mean temperature (degrees Celsius) during the time period of pseudothecia maturation and both the location parameter $(\delta)(F=14.91 ; P=$ $0.0017 ; R^{2}=0.516$ ) (Fig. 4A) and the number of asci that developed per pseudothecium $\left(F=29.28 ; P<0.0001 ; R^{2}=0.678\right)$ (Fig. $4 \mathrm{~B})$. The time period of pseudothecia maturation extended from the day of stem debris placement on the soil surface until the estimated date by which $50 \%$ of pseudothecia were mature. No sig- nificant $(P>0.05)$ linear regression was observed between the average mean temperature and the rate parameter $(\beta)(F=0.22 ; P=$ $0.6441)$. The location parameter $(\delta)$ and the number of asci formed per pseudothecium were directly or inversely proportional, respectively, to the average mean temperature during the time period of pseudothecia maturation (Fig. 4A and B).

\section{DISCUSSION}

The aim of our research was to determine the phenology of $D$. rabiei development on chickpea debris under diverse field conditions in the main chickpea-growing regions of Spain. Results indicate that $D$. rabiei can extensively colonize naturally infested chickpea stem debris left on the soil surface in these regions and form both viable pycnidia and pseudothecia. Both the extensive colonization of debris and differentiation of pseudothecia initials occurred regularly across locations. Ascospore maturation occurred mainly from late January to late March, and maximum discharge of ascospores occurred within 2 to 4 weeks of ascospore maturation.

The occurrence of the teleomorphic stage of A. rabiei on overwintering chickpea debris has been reported in different geographic areas of the world $(5,6,8-14,28)$. However, studies on pseudothecial development and maturation under field conditions are scarce. In Greece, immature and mature pseudothecia were observed on overwintering chickpea debris by the end of January and
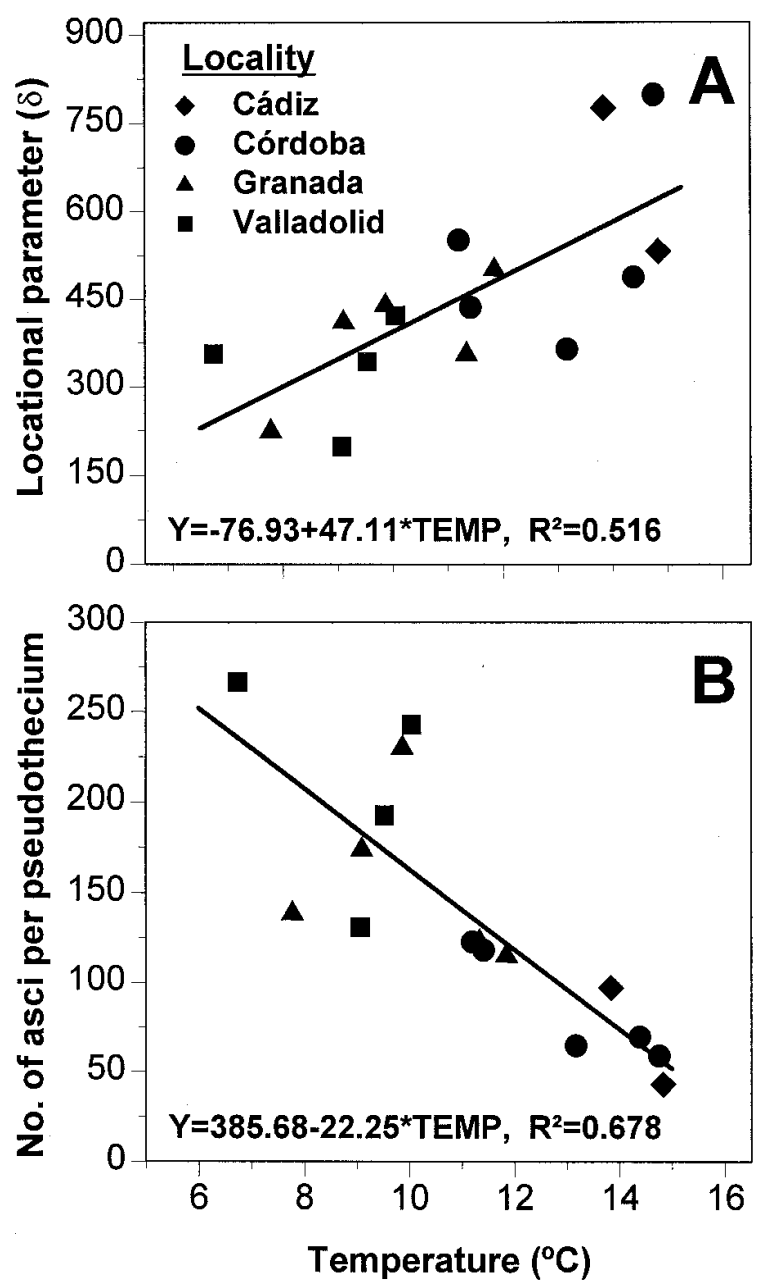

Fig. 4. Relationship between the average mean temperatures during the time period of pseudothecia maturation and $\mathbf{A}$, the location parameter and $\mathbf{B}$, the number of asci developed per pseudothecia of Didymella rabiei on chickpea stem debris incubated on the soil surface at different locations and during seasons in southern (Cádiz, Córdoba, and Granada) and northern (Valladolid) Spain. 
during February, respectively (28). In the U.S. Pacific Northwest, the teleomorph developed extensively on overwintering chickpea crop residues. Pseudothecia appeared during early fall, matured during fall and winter, and produced ascospores during spring (23). Mature pseudothecia also were observed during spring in Bulgaria (13) and Hungary (14). Our results on maturation of pseudothecia and production and release of ascospores from infested chickpea debris differed from those reported in Greece. Zachos et al. (28) indicated that mature pseudothecia with ascospores remained functional on chickpea debris for more than one season. The mild fall and winter temperatures and low rainfall in the region of study in Greece in 1961 (28) may explain these differences.

Several similarities and differences can be observed when comparing the phenology of $D$. rabiei pseudothecial development with that of other ascomycetes, e.g., Venturia inaequalis. In our study, pseudothecial development of $D$. rabiei proceeded uninterrupted after pseudothecia initials formed on infested chickpea debris. No constitutive dormancy was observed during any of the developmental stages, in contrast to the development of asci of $V$. inaequalis, which is initiated only after a dormant period, during which there is no observable development in the lumina of the pseudothecia (7). The development of pseudothecia of $D$. rabiei was correlated significantly with the environmental conditions prevailing at each experimental location during each season. Thus, the period of time required for pseudothecial maturation and ascospore production was determined by the mean average temperature and rainfall during that period. In our previous studies under laboratory conditions $(16,18)$, relative humidity was the limiting factor for pseudothecial development of D. rabiei. No development of pseudothecia occurred in air-dried chickpea stems, and mature pseudothecia were observed only in chickpea stems incubated at continuous $100 \% \mathrm{RH}$ or alternating 100 and $34 \% \mathrm{RH}$.

The importance of moisture for pseudothecial development of D. rabie $i$ was noted several times during the 5 years of this field study. No further pseudothecial developmental progress was observed during dry periods, and the latest pseudothecia development occurred during years for which rainfall during spring was lower than that during average years. Thus, delayed ascospore maturation occurred with prolonged dry periods at Valladolid (northern Spain) during the 1988-1989 season and at Granada (southern Spain) during the 1989-1990 season. Also, delayed ascospore maturation occurred when rainfall was below normal and irregularly distributed at all locations during late winter and spring of the 1990-1991 season and especially during the 1991-1992 season (Fig. 2). In contrast, ascospores matured earlier at Córdoba during the 1987-1988 season, where frequent heavy rainfall occurred during winter (Fig. 2). Moisture also was essential for pseudothecial initiation and development of $V$. inaequalis. In field experiments (7), pseudothecial development of $V$. inaequalis was correlated with rainfall and high relative humidity, and as for D. rabiei, dry periods or below normal rainfall delayed ascospore maturation $(7,27)$. Ascospore discharge in D. rabiei was stimulated by rainfall (23), and therefore, the time span of this phase was regulated by the frequency of rains.

When moisture was not a limitation, temperature in our field study had a major influence on pseudothecial development of $D$. rabiei. The number of, and spore production in, pycnidia and pseudothecia was lower at the warmest locations in southern Spain (Cádiz and Córdoba) compared to those in the coolest locations in southern (Granada) and northern (Valladolid) Spain. Nevertheless, although major differences were observed in the development of pseudothecia (Figs. 2 and 3) and the quantitative production of pseudothecia and ascospores (Fig. 1B and D), a narrower range of variation was observed for the production of pycnidia and conidia (Fig. 1A and C).

The time required for pseudothecial maturation and ascospore production was correlated with the average mean temperature and rainfall during the period of pseudothecial maturation (Fig. 4B). Under controlled conditions $(16,18,23)$, if relative humidity was favorable for the initiation and development of pseudothecia of $D$. rabiei, the optimum temperature for pseudothecial maturation ranged from 5 to $10^{\circ} \mathrm{C}$. Most pseudothecia degenerated at $15^{\circ} \mathrm{C}$, and all failed to produce asci and ascospores at 20 and $25^{\circ} \mathrm{C}(16,18,23)$. Average mean temperatures for the time period of pseudothecial maturation during the seasons in our study were 8.8, 10.0, 13.0, and $14.3^{\circ} \mathrm{C}$, at Valladolid, Granada, Córdoba, and Cádiz, respectively. Therefore, favorable temperatures for pseudothecial development occurred more frequently at Valladolid and Granada compared to Córdoba and Cádiz. Low temperature and a relatively long incubation period are requirements for sexual reproduction in many plant-pathogenic members of ascomycotina (15), and the genus Didymella is no exception (3), although some very wellknown plant-pathogenic species, such as D. bryoniae, D. ligulicola, and $D$. pinodes, do not share these requirements $(2,20,25)$.

Fall-winter and early-spring sowings of chickpeas are more exposed to airborne ascospore inoculum of $D$. rabiei than traditional late-spring sowings, because the time period of the earlier sowings coincides with ascospore production by the pathogen on chickpea debris $(23,24)$. Nevertheless, our results show that ascospores can be an important primary inoculum for traditional spring sowings of chickpea in Spain and perhaps in other chickpeagrowing areas in the Mediterranean Basin with similar climatic conditions. During the 5 years of our study, there was a remnant of ascospores whose release coincided with the early vegetative stages of late spring-sown chickpea crops.

In crop seasons with below-normal precipitation during the fallwinter period, pseudothecia maturation and ascospore release are delayed until mid- or late spring, ensuring good synchronization between ascospore availability and vegetative stages of spring-sown chickpea. Ascospores are released when environmental conditions are favorable for development of the disease, which increases their efficiency as primary inoculum for Ascochyta blight epidemics.

In summary, the traditional cycle of pathogenesis, which considers splash-dispersed conidia release from pycnidia on seeds, crop debris, and volunteer plants as the only primary inoculum for Ascochyta blight, needs to be modified for the major chickpea-growing regions in Spain to account for production of airborne ascospores on chickpea debris. Therefore, new disease management strategies are needed to reduce or prevent production of ascospores on chickpea crop residues and their dispersal to distant, healthy chickpeas.

\section{ACKNOWLEDGMENTS}

Research was supported by grants CCA-8510/30 from the U.S.-Spain Joint Committee for Scientific and Technological Cooperation, PIR 89/2 from Junta de Andalucía, and AGR 89-0260 from Comisión Interministerial de Ciencia y Tecnología of Spain.

\section{LITERATURE CITED}

1. Campbell, C. L., and Madden, L. V. 1990. Introduction to Plant Disease Epidemiology. John Wiley \& Sons, New York.

2. Chiu, W. F., and Walker, J. C. 1949. Morphology and variability of the cucurbit black rot fungus. J. Agric. Res. 78:81-102.

3. Corbaz, R. 1957. Recherches sur le genre Didymella Sacc. Phytopathol. Z. $28: 375-414$.

4. Gomez, K. A., and Gomez, A. A. 1984. Statistical Procedures for Agricultural Research. 2nd ed. John Wiley \& Sons, New York.

5. Gorlenko, M. V., and Bushkova, L. N. 1958. Perfect stage of the causal agent of ascochytosis of chickpea. Plant Prot. Moscow 3:60 (In Russian).

6. Haware, M. P. 1987. Occurrence of perfect state of Ascochyta rabiei in Syria. Int. Chickpea Newsl. 17:29-30.

7. James, J. R., and Sutton, T. B. 1982. Environmental factors influencing pseudothecial development and ascospore maturation of Venturia inaequalis. Phytopathology 72:1073-1080.

8. Jiménez-Díaz, R. M., Navas-Cortés, J. A., and Trapero-Casas, A. 1987. 
Occurrence of Mycosphaerella rabiei, the teleomorph of Ascochyta rab$i e i$ in Andalucía. Pages 124-125 in: Proc. 7th Congr. Mediterr. Phytopathol. Union. Consejería de Agricultura y Pesca de la Junta de Andalucía, Granada, Spain.

9. Kaiser, W. J., and Hannan, R. M. 1987. First report of Mycosphaerella rabiei on chickpeas in the Western Hemisphere. Plant Dis. 71:192.

10. Kaiser, W. J., and Küsmenoglu, I. 1997. Distribution of mating types and the teleomorph of Ascochyta rabiei on chickpea in Turkey. Plant Dis. 81: 1284-1287.

11. Kaiser, W. J., and Muehlbauer, F. J. 1989. An outbreak of Ascochyta blight of chickpea in the Pacific Northwest, USA, in 1987. Int. Chickpea Newsl. 18:16-17.

12. Kaiser, W. J., and Okhovat, M. 1996. Distribution of Didymella rabiei, the teleomorph of Ascochyta rabiei, in Iran. Iran. J. Plant Pathol. 158-162.

13. Kovachevski, I. C. 1936. The blight of chickpea (Cicer arietinum), Mycosphaerella rabiei n. sp. Ministry of Agriculture and National Domains, Plant Protection Institute, Sofia, Bulgaria. (In Bulgarian).

14. Kövics, G., Holly, L., and Simay, E. I. 1986. An ascochytosis of the chickpea (Cicer arietinum L.) caused by Didymella rabiei (Kov.) v. Arx: Imperfect Ascochyta rabiei (Pass.) Lab. in Hungary. Acta Phytopathol. Entomol. Hung. 21:147-150.

15. Müller, E., and von Arx, J. A. 1962. Die Gattungen der didymosporen Pyrenomyceten. Beitr. Kryptogamenflora Schweiz 11:1-922.

16. Navas-Cortés, J. A. 1992. El teleomorfo de Ascochyta rabiei (Pass.) Labrousse en España: Detección, desarrollo y su papel en la epidemiología de la Rabia del Garbanzo (Cicer arietinum L.). Ph.D. thesis. Escuela Técnica Superior de Ingenieros Agrónomos y de Montes, University of Cordoba, Spain.

17. Navas-Cortés, J. A., Trapero-Casas, A., and Jiménez-Díaz, R. M. 1995. Survival of Didymella rabiei in chickpea straw debris in Spain. Plant Pathol. 44:332-339.

18. Navas-Cortés, J. A., Trapero-Casas, A., and Jiménez-Díaz, R. M. 1998. Influence of relative humidity and temperature on development of Didy- mella rabiei in chickpea debris. Plant Pathol. 47:57-66.

19. Nene, Y. L., and Reddy, M. V. 1987. Chickpea diseases and their control. Pages 233-270 in: The Chickpea. M. C. Saxena and K. B. Singh, eds. CAB International, Oxon, England.

20. Punithalingam, E., and Holliday, P. 1972. Mycosphaerella pinodes. No. 340 in: Descriptions of Pathogenic Fungi and Bacteria. Commonwealth Mycological Institute, Kew, England.

21. Trapero-Casas, A., and Jiménez-Díaz, R. M. 1984. Siembras tempranas y Rabia del garbanzo. Page 95 in: Actas 3rd Congr. Nacional Fitopatol. Sociedad Española de Fitopatología, Puerto de la Cruz, Tenerife, Spain.

22. Trapero-Casas, A., and Jiménez-Díaz R. M. 1986. Influence of sowing date on Fusarium wilt and Ascochyta blight of chickpea in Southern Spain. Page 11 in: Poster Abstr. Int. Food Legume Conf. L. E. O'Keeffe and F. J. Muehlbauer, eds. College of Agriculture, University of Idaho, Moscow.

23. Trapero-Casas, A., and Kaiser, W. J. 1992. Development of Didymella rabiei, the teleomorph of Ascochyta rabiei, on chickpea straw. Phytopathology 82:1261-1266.

24. Trapero-Casas, A., Navas-Cortés, J. A., and Jiménez-Díaz, R. M. 1996. Airborne ascospores of Didymella rabiei as a major primary inoculum for Ascochyta blight epidemics in chickpea crops in southern Spain. Eur. J. Plant Pathol. 102:237-245.

25. Walker, J., and Baker, K. F. 1983. The correct binomial for the chrysanthemum ray blight pathogen in relation to its geographical distribution. Trans. Br. Mycol. Soc. 80:31-38.

26. Wilson, A. D., and Kaiser, W. J. 1995. Cytology and genetics of sexual incompatibility in Didymella rabiei. Mycologia 87:795-804.

27. Wilson, E. E. 1928. Studies of the ascigerous stage of Venturia inaequalis (Cke.) Wint. in relation to certain factors of the environment. Phytopathology 18:375-418.

28. Zachos, D. G., Panagopoulos, C. G., and Makris, S. A. 1963. Recherches sur la biologie, l'épidémiologie et la lutte contre l'anthracnose du poischiche. Ann. Inst. Phytopathol. Benaki 5:167-192. 